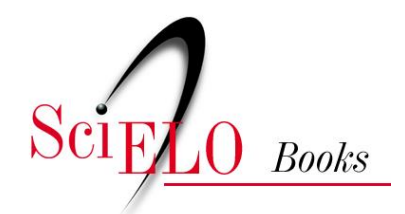

\title{
Traços Foucaultianos recorrentes
}

\author{
Jorge Alberto Rocha
}

\section{SciELO Books / SciELO Livros / SciELO Libros}

ROCHA, JAC. Traços Foucaultianos recorrentes. In: Michel Foucault: crítico-esteta-cínico mitigado [online]. Campina Grande: EDUEPB, 2014. Substractum collection, pp. 31-80. ISBN 978-85-7879-

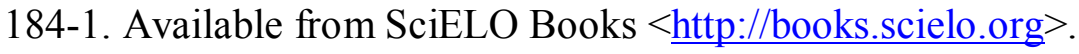

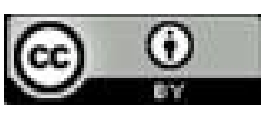

All the contents of this work, except where otherwise noted, is licensed under a Creative Commons Attribution $\underline{4.0 \text { International license. }}$

Todo o conteúdo deste trabalho, exceto quando houver ressalva, é publicado sob a licença Creative Commons Atribição 4.0.

Todo el contenido de esta obra, excepto donde se indique lo contrario, está bajo licencia de la licencia $\underline{\text { Creative }}$ Commons Reconocimento 4.0. 


\section{Traços Foucaultianos recorrentes}

\section{Do "jornalista" ao "arqueólogo"}

As curiosidades que algumas expressões dos filósofos despertam em geral só têm razão de ser quando ainda se está situado em um plano de entendimento insatisfatório e mediano. Tal é a possível perplexidade ao se ouvir a expressão: "Foucault, um jornalista"; ou então, a filosofia, "uma espécie de jornalismo radical". Essa ideia foucaultiana surgiu em um pequeno texto na revista francesa Manchete, em 1973. Pequeno, mas portador de uma ideia bastante vigorosa: instaurado a partir do século XIX com o fim do absolutismo, o mundo se tornou um grande asilo, uma vez que os governos puderam aliar-se aos diversos saberes existentes e passar a exercer uma "terapêutica" populacional, nova função do poder político (FOUCAULT, "À propos de l'enfermement pénitentiaire”, DE, I, 2001, p. 1304).

A questão do jornalismo (filosófico) aparece aí. Obviamente, não o tomando numa acepção usual, quando pensado nos profissionais da comunicação voltados para relatar notícias ao grande público ou, de forma geral, fazer circular as informações planetárias. A exemplo de Nietzsche, "o primeiro deles", 
ele [Foucault] se considerava um "jornalista" referindo-se a um aspecto principal desse labor, embora o aprofundando: $\mathrm{o}$ sentido de ser do seu interesse o que está passando, a atualidade ou o acontecimento (FOUCAULT, "Le monde est um grand asile", DE, I, 2001, p. 1302; FOUCAULT, "La scène de la philosophie", DE, III, 1994, p. 573), algo a ser retomado no segundo Capítulo desta tese, tentando perceber as ressonâncias kantianas; mas, por hora, cabe algumas indicações sobre o termo, principalmente referindo-se a Friedrich Nietzsche.

O gerúndio acima, declinado do verbo "passar", já tinha neste autor uma extensão bastante ampla. Um "acontecimento" não precisa ser um "fato objetivo", pode ser uma situação exposta através de uma construção filosófica. Foi o caso da teoria da "morte de Deus". Para Nietzsche o "acontecimento" significativo atrelado ao homem moderno é que este era o último dos homens; quer dizer, atingindo um vértice de crise, Zaratustra vislumbra duas alternativas: ou permanecerá o homem como está, ou tal homem será "ultrapassado", tornando-se um übermench, ${ }^{6}$ aquele que conseguiu se equilibrar na ponte sob o precipício (da criticada modernidade) e avançar: "O homem é uma corda estendida entre o animal e o Super-humano - uma corda sobre um abismo. É perigoso transpor o abismo - é perigoso ir por este caminho - é perigoso olhar para trás - é perigoso ter uma tontura e parar de repente!" (NIETZSCHE, 2004, p. 25). ${ }^{7}$

6 Por conta de uma referência menos comprometida com imagens fílmicas traduz-se melhor übermench por além-do-homem ou super-humano, ao invés de super-homem.

7 Para Michel Foucault Nietzsche faz do além-do-homem aquele que deverá ocupar o "vazio metafísico", estando ausentes agora o homem e Deus (FOUCAULT, “Nietzsche, Freud, Marx”, DE, I, 1994, p. 553). 
Giacoia também cita esta teoria, remetendo ao personagem do Zaratustra nietzscheano: "porta-voz de doutrinas fundamentais para o futuro do homem" (GIACOIA, 2000, p. 56), a nova qualidade em voga deveria apontar, pois, para um "além-do-homem" que, na sua captação imprecisa, por parte de Nietzsche, de qualquer maneira viria a se opor ao "último homem" ou homem moderno, à "decadência" e "niilismo" que o assolam. Assim, escreve mais uma vez Nietzsche:

Descobrimos a felicidade, sabemos o caminho, encontramos a saída do labirinto através de milhares de anos. Quem a encontrou? O homem moderno talvez? - 'Eu não sei sair nem entrar' - suspira o homem moderno... (NIETZSCHE, 2001, p. 13).

Todas as coisas de que a época se orgulha são percebidas [Nietzsche está se referindo ao livro Além do bem e do mal] como contrárias a esse tipo [nobre de homem], como más maneiras quase, por exemplo a famosa 'objetividade', a 'compaixão pelo sofredor', o 'sentido histórico', com sua submissão face ao gosto alheio, com seu arrastar-se ante os petits faits, a 'cientificidade' (NIETZSCHE, 1995, p. 95).

O movimento filosófico de Zaratustra é justamente um levante contra o reverso da busca pelo profundo. A ideia do oculto, de que há uma essência ou substância no âmago dos entes marcou a filosofia desde os gregos, fazendo da verdade o último passo em prol do desvelamento das coisas; ou, mais modernamente, há de se expurgar ora as incertezas 
proporcionadas pelos meus sentidos corpóreos (Descartes), ${ }_{1}^{8}$ ora atentar para os ídolos que, muito naturalmente, corrompem a apreensão correta do mundo ao meu redor, fazendo-o cintilar na sua pureza de ser. Mas Zaratustra des-cobre algo diferente: que "a profundidade era um jogo, e uma dobra da superfície", como na pretensa fundamentação da moralidade, ao invés de ver aí uma correlação de forças (NIETZSCHE, 1983). Na perspectiva foucaultiana, nada há para interpretar, uma vez que tudo já é "interpretação de interpretação" (FOUCAULT, "Nietzsche, Freud, Marx", DE, I, 1994, p. 575). ${ }^{9}$

Deleuze percebeu claramente esta inclinação de Nietzsche, pensa Foucault, levando-a para além de uma "metafísica da substância" ou uma "coerência causa-efeito". Considerando de Deleuze as obras Diferença e repetição e Lógica do Sentido como dois textos maiores, e que ressoarão em nós por muito tempo ainda, fazer aparecer o acontecimento significa "submergir a aparência" mesma, abrindo as portas para todos os simulacros; uma tarefa que implica perverter Platão, num deslocamento "até a maldade dos sofistas, aos gestos mal educados dos cínicos, aos argumentos dos estóicos,

8 A referência aqui é às Meditações cartesianas, e ao recurso exemplar deste autor ao falar sobre a cera, o autômato e o sonho (DESCARTES, 1979). Os ídolos se referem às teorias de Bacon.

9 Aos que objetam a ausência primeira de Hegel dentro desta tarefa interpretativa, Foucault responde que estava fazendo uma arqueologia do pensamento, não uma história da filosofia. E na resposta a Vattimo, dizer que Marx se insere na perspectiva de uma interpretação infinita, apesar de a infra-estrutura parecer o contrário disso, Foucault o responde, dizendo que Marx não apresentou a sua interpretação como análise final, como exposta em o 18 Brumário (FOUCAULT, "Nietzsche, Freud, Marx", DE, I, 1994, p. 576). 
às quimeras revoluteantes de Epicuro. Leiamos Diógenes Laércio" (FOUCAULT, "Theatrum philosophicum", DE, I, 2001, p. 946).

$\mathrm{O}$ "jornalismo" foucaultiano, feito na esteira daquilo que "está passando", recusa-se, porém, a fazer prognósticos (uma das maiores crítica de Foucault a Marx). Ele passa pela compreensão de que os escritos (outra matéria-prima do jornalismo) são prisões, caso se os adote como algo que quer selar notações definitivas para aquilo do qual versa. Significa isso dizer que no acontecimento vai haver uma preocupação não de se voltar para determinar, por exemplo, o ser dos entes, como no já conhecido questionamento heideggeriano: "Ente no ser. Isso se tornou para os gregos o mais espantoso" sendo, ao mesmo tempo, um "esquecimento" do Ocidente (HEIDEGGER, 1979, p. 17).

Ora, para Michel Foucault a tarefa da atividade discursiva deve ser outra. Novamente, assim como na prática jornalística, alimentada por situações diárias, escreve-se para dar conta de algo que está aí, em voga. Depois, isso não existe mais e, como no exemplo de um livro escrito, este deveria ser posto de lado: "Eu penso para esquecer", fala Foucault na entrevista "Le grand enfermement". Não que as palavras e ideias, uma vez atadas com tinta e papel, devessem em seguida ser abandonadas. A questão é fazer explodir os escritos, levá-los para outras plagas. No caso desta entrevista citada, que se torna elucidativa para aquilo do qual está-se falando, deverse-ia pensar menos em uma sequência de Histoire de la folie (2003a), algo "desprovido de interesse", do que em resvalar possíveis noções ali presentes na direção de situações mais emergenciais. Assim, "uma ação política concreta em favor 
dos prisioneiros me parece carregada de sentido. Uma ajuda à luta dos detentos e, finalmente, contra o sistema que os põe na prisão" (FOUCAULT, "Le grand enfermement", DE, I, 2001, p. 1172-1173).

Em outro lugar encontra-se ideias similares, numa aproximação foucaultiana da filosofia com uma sua finalidade bélica, ao invés de "representativa", talvez já marcando uma das grandes características da contemporaneidade: pois para que servem os escritos, senão para ser uma artilharia pesada de guerra que, uma vez destruído o seu alvo, deve se encaminhar para outras regiões de conflito? É a ideia de livro-bomba: "coquetéis molotov ou galerias de minas, carbonizando-se após o uso como fogos de artifício" (FOUCAULT, "Sur la sellette", DE, I, 2001, p. 1591). Afinal, de que adianta construir um livro-instrumento se este muitas vezes é apropriado indevidamente, como o fez o Estado prussiano, com Hegel, e Napoleão, com Rousseau, a partir do século XVII, além do nazismo, atravessando Wagner e Nietzsche, mais próximo da época atual?

Ora, essas filosofias da liberdade deram ao mesmo tempo lugar a formas de poder que, seja sob a forma do terror, seja sob a forma da burocracia, seja ainda sob a forma do terror burocrático, eram o contrário mesmo do regime de liberdade, o contrário mesmo da liberdade tornada história (FOUCAULT, "Dialogue sur le pouvoir", DE, III, 1994, p. 476 e 539). 
$\mathrm{O}$ "acontecimento" foucaultiano tem, pois, algumas linhas dissonantes em relação aos filósofos que o precederam, conquanto guarde o sentido geral. É necessário tentar perceber as suas nuances. Num deslocamento em relação a Kant, que tentava compreender a sua época como um todo, Foucault, buscando estudar o "acontecimento", vê que este não se reduz "nem à lei geral de um progresso, nem ao retorno ou repetição de uma origem" (FOUCAULT, "Réponse à Derrida", DE, I, 2001, p. 1150).

Foucault declina ainda tal substantivo para uma sua forma verbal. Assim, trata-se de "acontecimentalizar" [événementialiser] cada objeto investigado, atento às seguintes características: de início, realizar uma ruptura daquilo que é evidente. Quando se rompem as evidências imediatas, fazendo surgir "singularidades", todas são regidas pelo princípio da nãonecessidade e da não-evidência do seu aparecimento. Ora, se se as rompe significa que foi posto em dúvida o que diz o saber atual, o que se assente cotidianamente e aquilo que faz parte das práticas realizadas. Para Foucault, isso é a "primeira função teórico-política" do termo (FOUCAULT, "Table ronde du 20 mai", DE, IV, 1994, p. 23).

Em segundo lugar, o que se tornou evidente, ou melhor, o que vai funcionar como evidente, universal e necessário, nessa perspectiva da "acontecimentalização", nasceu das conexões, encontros, apoios, bloqueios, jogos de força e estratégias que o genealogista deve tentar "reencontrar". É o sentido da chamada "demultiplicação causal", que Foucault chega a enumerar em três características: 1) tomando o exemplo da prisão há uma "multiplicidade" que a envolve: processos de "penalização" das antigas práticas, inserindo nelas 
progressivamente "formas da punição legal"; e processos de "'carceralização' de práticas da justiça penal", por onde a prisão se tornou a "peça central" como "forma de castigo" e "técnica de correção" - todos esses processos devendo ainda ser decompostos, por exemplo quando se vê neles "espaços pedagógicos fechados", coexistindo no seu interior; 2) "'polígono" ou "'poliedro de inteligibilidade'", construído em torno do acontecimento em causa, nunca inteiramente acabado, mas sempre aberto a novas relações, racionalizáveis entre si; por fim, 3) polimorfismo múltiplos: "de elementos" (como na relação prisão-práticas pedagógicas); "de relações descritas" (como na "transferência de modelos técnicos", como o modelo arquitetônico de Bentham); de "cálculos táticos" (como o "crescimento do banditismo"); ou "aplicação de esquemas teóricos" (como as ideias são dispostas, ora de forma utilitarista, ora com outras características); e "polimorfismo nos domínios de referência", ou seja, as diversas mutações técnicas que se verificam, bem como as novas técnicas de poder que se lançam mão (FOUCAULT, "Table ronde du 20 mai", DE, IV, 1994, p. 24-25).

Em $A$ ordem do discurso Foucault demarca um conceito de acontecimento. Assim, este não é

[...] nem substância nem acidente, nem qualidade, nem processo; o acontecimento não é da ordem dos corpos. Entretanto, ele não é imaterial; é sempre no âmbito da materialidade que ele se efetiva, que é efeito; ele possui seu lugar e consiste na relação, coexistência, dispersão, recorte, acumulação, seleção de elementos materiais; não é o ato nem a propriedade de 
um corpo; produz-se como efeito de e em uma dispersão material. Digamos que a filosofia do acontecimento deveria avançar na direção paradoxal, à primeira vista, de um materialismo do incorporal (FOUCAULT, 1996, p. 57).

Em "Theatrum philosoficum", artigo publicado também no ano de 1970, um mês antes da sua aula inaugural, Foucault já tinha se detido acerca do événement, tendo por mote abordar positivamente as obras Diferença e Repetição e Lógica do sentido, de Gilles Deleuze. Com efeito, escreve Foucault, a Física fala de causas. $\mathrm{O}$ acontecimento, porém, de efeitos, de corpos que se entrechocam. É o lugar do acontecimento-sentido, de um quarto elemento acrescido dos três que a lógica tradicional ensinou. Assim, na expressão "'Marco Antônio está morto'", há o momento da "designação" desse ocorrido, desse "estado de coisas"; segundo, da "expressão" de uma opinião ou crença; terceiro, "significa uma afirmação". Mas haveria ainda um quarto lugar a ser preenchido, o lugar do "sentido" morrer. Nesse caso, duas faces a serem constatadas: uma "virada para as coisas" (quer dizer, o acontecimento da morte de alguém), e a outra "virada para a proposição"; mas, bem entendido, sendo esse sentido sempre um "impalpável", quer dizer, tomando o exemplo acima, estar morto não teria o seu sentido demarcado como atributo (o vermelho como cor de um automóvel, por exemplo), senão como "verbo (morrer; viver, avermelhar)" (FOUCAULT, "Theatrum philosoficum", DE, I, 2001, p. 949-950).

Mas, trabalhando o "acontecimento", não estaria Foucault próximo do "historiador"? Uma primeira abordagem a ser 
feita, contudo, é sobre como entender a compreensão histórica. Uma passagem sinaliza, em Foucault, momentos que foram superados por uma investigação histórica mais pertinente. Assim, antes a história trabalhava com o tempo e o passado, agora ela trabalha com a mudança e o acontecimento ("Revenir à l'histoire", DE, I, 2001, p. 1141). Antes, pensando em historiadores como Lucien Febvre ou Marc Bloch, os acontecimentos históricos eram tomados em sua descrição corriqueira (eventos e datas) e visando a estruturas a serem descobertas, enquanto que agora a noção de acontecimento se impõe com a sua força.

Foi baseado em linhas investigativas como essas que a história se inseriu nas reflexões foucaultianas. Ela teve, inegavelmente, uma importância fundamental para Michel Foucault, desde os seus estudos da década de 1960, começando com Histoire de la folie ${ }^{10}$ até os anos 80, com a publicação dos volumes da sua História da sexualidade. Outra razão disso, segundo ele, é que "em uma cultura como a nossa todo discurso aparece sob o fundo de ausência de todo conhecimento" (FOUCAULT, "Sur les façons d'écrire l'histoire", DE, I, 1994, p. 598). Ou seja, em uma cultura sem história os discursos se justaporiam e seriam esquecidos, e isso não se admite.

$\mathrm{O}$ que não significa dizer que ele tenha desembocado para algo como um historicismo que, no século XIX, transformou a história no "poder legislador e crítico da filosofia" (FOUCAULT, "Sur les façons d'écrire l'histoire", DE, I, 1994,

10 Escrita de 1955 a 1960, como tese de doutorado, e vindo a público em 1961. 
p. 598), ${ }_{i}^{11}$ na verdade, o privilégio dado à história está em esta representar "o papel de uma etnologia interna de nossa cultura e de nossa racionalidade", frase compreendida segundo duas direções: interessa a Foucault, primeiro, analisar os "fatos culturais que caracterizam nossa cultura" (análise que passa por um viés filosófico, inserindo ideias e conceitos gerais explicativos) e, fazendo isso, em segundo lugar, cabe operar um "diagnóstico" do tempo presente.

Sem cair num historicismo e sem assumir para si a imagem do historiador, a história foi sempre o seu pano de fundo, uma estratégia até que visava "historicizar ao máximo para deixar o menor lugar possível ao transcendental" (FOUCAULT, “Les problèmes de la culture. Un débat Foucault-Preti", DE, I, 2001, p. 1241). Assim, enquanto que autores como Deleuze propuseram "conceitos quase brutos", embora comuns aos de uma linha teórica da sua geração (multiplicidade, diferença, repetição), Foucault os tratava com "mais mediações" (DELEUZE, 1990, p. 122), inserindo, por exemplo, acontecimentos históricos para ilustrá-los, debatê-los ou tomá-los como guia. Esse cuidado de se recusar a entrar no âmbito de uma "filosofia pura" não o eximiu, entretanto, da pecha de muitos dos seus comentadores, como Baudrillard (1984), Habermas (1990) ou Merquior (1988), que não deixaram de apontar características negativas relacionadas ao seu trabalho, como relativista, cético ou niilista.

11 Foucault e os estruturalistas não buscarão atacar os historiadores, mas um certo historicismo praticado por alguns, na valorização excessiva do sujeito agente da história (FOUCAULT, "Médicins, juges et sorciers au siècle XVII", DE, I, 1994, p. 774). 
Tratava-se antes de mostrar a necessidade doravante de empreender críticas a algumas linhas de investigação no manejo com a história, não cabendo apenas valer-se do material colhido no passado de forma indiscriminada ou menos atenta a algumas sutilezas teóricas imprescindíveis. Mas, então, não sendo historiador, seria ele um filósofo? Cabe adiantar que as soluções mistas parecem ser as mais adequadas. As suas obras, como ele mesmo escreveu em "Table ronde du 20 mai 1978" (DE, IV, 1994, p. 21), são "fragmentos filosóficos em canteiros históricos". Um canteiro que, na maior parte das vezes, é posto de lado ou desconhecido: "Os filósofos são, em geral, muito ignorantes de todas as disciplinas que não são as suas" (FOUCAULT, "Foucault répond à Sartre", DE, I, 1994, p. 667).

E a imagem a ser buscada tem a ver justamente com tal comparação: uma planta não se desenvolve sem um canteiro, um lugar de terra demarcado e propício para o seu crescimento, como a filosofia, ou uma reflexão, seja de que ordem for também não ganha em consistência sem o apoio dessa mediação histórica. Daí, nessa confluência jamais definitiva ele nem atribuir aos seus livros a qualificação de "tratados de filosofia nem de estudos históricos", mas a expressão precisa de "fragmentos" [fragments] desses saberes, proposta desde cedo ilustrada com a análise foucaultiana das experiências -limite do Ocidente, como foi o caso da loucura, mostrando tanto uma imersão no material histórico sobre o tema, quanto uma inclinação filosófica, tipicamente nietzscheana, no caso.

Assim, um autor preocupado com análises "fragmentárias" não deve estar voltado para dar conta de uma teoria ou temática de uma vez por todas demarcada; ele se volta 
para aspectos que considera relevantes, imprescindíveis na sua ótica e, sobretudo, "atuais", o que propicia uma volta à antiga imagem de jornalista. $\mathrm{O}$ acontecimento do qual uma análise histórica (ou de inclinação histórica) deve recusar os grandes objetos gerais: Feudalismo, Revolução Industrial etc. - concentrando-se, ao invés, em uma "história serial", justamente aquela que "define seu objeto a partir de um conjunto de documentos que dispõe" e visando à constatação das inúmeras "relações" que daí aparecem (perceberíamos, então, a singularidade de cada acontecimento. FOUCAULT, "Revenir à l'histoire", DE, I, 2001, p. 1141-1144). Ela faz aparecer coisas visíveis, mas também acontecimentos invisíveis. As descontinuidades dos acontecimentos se multiplicam, tornando-se descontinuidades superpostas. Em "Le savoir comme crime" (FOUCAULT, DE, III, 1994, p. 82), Foucault explica que entender a história como uma sucessão de fragmentos é o mesmo que entendê-la como uma "sucessão de acasos, de violência, de rupturas".

Assim, não se trata de escolhas à revelia, senão que o critério da atualidade está na base da tarefa de se efetuar os fragmentos de análise. No caso de "Table ronde Du 20 mai 1978", a escolha da prisão como tal objeto se deveu a dois fatores: ter sido ele um tema muito "negligenciado", pois só abordado do ponto de vista do "problema sociológico da população delinqüente" ou do problema "jurídico do sistema penal e de seu fundamento". Na época em que Foucault escreveu Surveiller et punir, diz ele, um "fato de atualidade" foi que "a prisão e mais geralmente numerosos aspectos da prática penal se encontravam colocados em questão" (FOUCAULT, "Table ronde Du 20 mai 1978", DE, IV, 1994, p. 21); por outro lado, Foucault pretendeu também retomar a genealogia da moral 
nietzscheana, "mas seguindo o fio do que se poderia chamar de 'tecnologias morais'" (FOUCAULT, "Table ronde Du 20 mai 1978", DE, IV, 1994, p. 21).

Outro aspecto que distancia Michel Foucault da prática do historiador é encontrado no curso do Collège de France. Aí ele começa o seu longo período de ensino com suas remarques de méthode (notas ou observações de método), tentando mostrar (1) a diferença básica entre se fazer uma história das ideias e uma história das mentalidades, esta tendo como papel realizar um foyer d'expérience, um lugar ou local onde se cruzam as três dimensões da experiência humana nas suas diversas relações na sociedade: uma certa forma de saber presente, uma matriz de comportamentos e a constituição de modos de ser do sujeito (FOUCAULT, 2008, p. 5). Em cada momento investigado a pergunta a ser feita é: o que dizer daquilo que está se passando atualmente? Significa isso, pois, dizer o acontecimento, como já se sabe, mas sem fazer o trabalho reservado ao historiador. ${ }^{12}$

A literatura está repleta de críticas a um Foucault cuja imagem é daquele que desvirtuou o trabalho do profissional de história e os seus livros foram alvos diretos dessas críticas (MERQUIOR, 1988). Mas ele se explicou por diversas vezes.

12 Não é preciso entrar nessa celeuma, mas é bom que se mencione as profundas críticas feitas por José Guilherme Merquior ao manejo da história por Michel Foucault. Para aquele, só para citar algumas delas, e relativamente à Histoire de la folie, Foucault teria abandonado, seguindo Nietzsche, a "pretensão da história de proporcionar neutralidade objetiva"; em segundo lugar, animado por uma necessidade de pôr os "loucos no papel de vítimas da sociedade", deixou de lado o importante papel que teria, de fato, a terapia, além de não ser fiel a inúmeros aspectos históricos descritos em torno do tema da desrazão (MERQUIOR, 1988, p. 48-49). 
Para ilustrar isso um caso pode ser exemplar: em Les mots et les choses o problema de muitos críticos estava em serem imbuídos de uma perspectiva teórica pela qual os acontecimentos históricos precisavam ser justificados; a história era interpretada modus dialético, dentro de uma ordem que se supunha existir previamente e, neste sentido, onde as contradições eram apenas etapas passageiras do projeto histórico global. Contra isso as novas abordagens históricas começam a questionar essa propensão teleológica, repensando igualmente a linha diretriz da causalidade no método de investigação histórico (FOUCAULT, "Sur les façons d'écrire l'histoire", DE, I, 1994, p. 586). Era preciso avançar rumo a uma análise arqueológica.

Ao invés de fazer história, de assumir a imagem de historiador, portanto, Foucault vai traçar uma diferença profunda em relação a tal prática, perfazendo agora o caminho do arqueólogo, termo que sinalizava algo de importante até mesmo por ter aparecido no prefácio de Histoire de la folie, no subtítulo de Les mots et les choses e em Naissance de la clinique. Nos Dits et écrits observa-se explicações importantes acerca do seu significado e, desta vez, até pelo menos os anos de 1960, uma imagem aceita por Michel Foucault, até partir para uma outra "dimensão" a partir dos anos de 1970: a do genealogista (abordada no capítulo III).

Como pode ser visto nos Dits et écrits a arqueologia não é parenta nem da geologia, como análise dos subsolos, nem da genealogia, como descrição dos começos e suas seqüências (FOUCAULT, "Sur les façons d'écrire l'histoire", DE, I, 1994, p. 595). É a "análise do discurso em sua modalidade de arquivo", isto é, uma investigação acerca da "existência acumulada dos discursos" (FOUCAULT, "Sur les façons d'écrire 
l'histoire", DE, I, 1994, p. 595), da "massa verbal" fabricada pelos homens, "investida em suas técnicas e suas instituições" (FOUCAULT, "La naissence d'un monde", DE, I, 2001, p. 814). ${ }^{13}$ Diferenças fundamentais em relação ao Estruturalismo, tão valorizado por Michel Foucault nos anos de 1960: menos interessado pelas "possibilidades formais oferecidas por um sistema como a língua", o "arquivo" é o que se tornou o seu objeto de investigação. Esse conceito foucaultiano fundamental merece ser pontuado.

O arquivo analisará: 1) "os limites e as formas de dizibilidade" (o que é possível falar em determinada época? Em certo domínio discursivo, quais as características de tal discursividade?); 2) "os limites e as formas de conservação" (quais discursos podem ser reutilizados e quais os que devem ser "reprimidos e censurados"?); 3) "os limites e as formas da memória" (quais os anunciados reconhecíveis como válidos e inválidos?); 4) "os limites e as formas de reativação" (tendo em vista discursos estrangeiros ou de épocas passadas, quais deles são apropriados, reconstruindo-os ou os transformando?); 5) "os limites e as formas de apropriação", significando isso perguntar:

Quais indivíduos, quais grupos, quais classes têm acesso a tal tipo de discurso? Como é institucionalizada a relação do discurso com aquele que o detém, com aquele que o recebe? Como se assinala e

13 Em "Médicins, juges et sorciers au XVII siècle" (FOUCAULT, DE, I, 1994, p. 773) ele acrescenta que o "estudo dessa massa verbal endereçase para o seu funcionamento, transformações e abertura para o surgimento de outros discursos". 
se define a relação do discurso com o seu autor? Como se desenrola, entre classes, nações, coletividades liguísticas, culturais ou étnicas, a luta para o domínio dos discursos (FOUCAULT, "Réponse à une question", DE, I, 1994, p. 682)?

Nesse sentido, a proposta foucaultiana não pensa em uma "história do espírito" (ligada às noções majoritárias de consciência e vontade do sujeito), muito menos no "sistema da sua língua". No primeiro caso há a recusa em se entender o percurso histórico humano como uma vasta evolução das ideias ou entendimentos relativamente ao real; no segundo caso ele se afasta de uma preocupação estruturalista fundamental, juntamente com uma possível necessidade de se fazer uma análise semântica e gramatical. Voltando-se para uma "história do discurso" a preocupação de Michel Foucault se afasta de uma análise dos códigos e se aproxima de uma análise "dos acontecimentos", neste caso da "lei da existência dos enunciados, o que os torna possíveis", a saber, as condições pelas quais se dá a sua emergência e a rede de suas correlações (FOUCAULT, “Réponse à une question”, DE, I, 1994, p. 681).

Através da visada arqueológica trata-se de apreender o que está na superfície de um sistema discursivo, mas que às vezes não se percebe (FOUCAULT, "Michel Foucault explique son dernier livre", DE, I, 1994, p. 772), suas formações inconscientes. ${ }^{14}$ Curioso é que esta posição metodológica não estava clara para ele, uma vez que, escrevendo Histoire de la

14 O caráter inconsciente das formações discursivas abriu margem para críticas acerca do papel do sujeito nos processos ligados ao conhecimento, crítica esta também dirigida à corrente estruturalista. 
folie e Naissance de la clinique "eu pensava [vai dizer Foucault], no fundo, estar fazendo história das ciências", visão transformada por ter compreendido em Les mots et les choses que, "independentemente da história tradicional das ciências, um outro método era possível, que consistia em uma certa maneira de considerar menos o conteúdo da ciência do que sua própria existência" (FOUCAULT, "Entretien avec Michel Foucault", DE, I, 2001, p. 1025). ${ }^{15}$ Incursionando por aí começa a perceber igualmente que a atividade científica é uma prática histórica; que é possível analisá-la sem se referir ao seu conteúdo e organização formal, senão vendo que ela possui certas "funções" na sociedade, certamente não apenas atreladas a uma busca desinteressada pela verdade ou realidade.

Algo que não deve levar a se adotar uma posição marxista, segundo a qual as "formações econômicas e sociais pré-discursivas" burguesas terminam por contaminar as formações discursivas das ciências. Para Michel Foucault esse posicionamento peca pela sua simplicidade, haja vista de forma alguma dar conta de "todas as regras [que definem] os objetos possíveis, a posição do sujeito com relação aos objetos e a maneira de formar os conceitos" (FOUCAULT, “Entretien avec Michel Foucault", DE, I, 2001, p. 1029).

Neste sentido, a arqueologia é um "domínio de investigação" ao invés de ser uma disciplina, encontrando o seu material não em livros científicos, filosofias ou justificações religiosas, mas, até em se partindo deles, na procura de se

15 Nesta obra, "um olho estava aberto e o outro fechado" no tocante à compreensão do método arqueológico, visão só aberta por completo a partir de L'Archeologie du savoir (FOUCAULT, "Entretien avec Michel Foucault", DE, I, 2001, p. 1026). 
entender como esses discursos foram possíveis, juntamente com as "práticas" igualmente operadas. Os centros de internamento do século XVII só se abriram em função da existência de certo saber acerca da loucura. As análises arqueológicas ganham corpo, assim, no conjunto de técnicas, instituições, esquemas de comportamento, tipos de transmissão e difusão e formas pedagógicas (FOUCAULT, "La volonté de savoir", DE, I, 2001, p. 1109.), e buscam ver não propriamente o "documento" histórico como algo a interpretar, na determinação da sua verdade, mas no estabelecimento de suas "séries" (FOUCAULT, 2003b, p. 5-9).

Gilles Deleuze interpretou as duas primeiras fases de Foucault (a arqueológica e a genealógica, mas aqui citada só em referência à primeira) como o percurso "do arquivo ao diagrama". O arquivista trata de enunciados, não de proposições ou frases. Esses anunciados são "raros", pois são aquilo que, na frase, é negado, aquilo que lhe é oculto. E o oculto são as regras concernentes à sua distribuição e reprodução, donde "sujeito, objeto, conceito são apenas funções derivadas da primitiva ou do enunciado" (DELEUZE, 1988, p. 20). Mas, nesse sentido, o enunciado não é plenamente oculto, embora também não seja visível (DELEUZE, 1988, p. 27).

A arqueologia foucaultiana pretende, dessa forma, distinguir "saber", como condição de possibilidade de teorias, opiniões e práticas, na sua diferença em relação a "conhecimentos", encontrados em livros científicos, filosofias, religiões etc. Isso evitaria, por exemplo, o problema da dita "anterioridade da teoria com relação à prática, e inversamente" (FOUCAULT, "Michel Foucault, 'Les Mots et les choses'", DE, I, 2002a, p. 526). Mas o fundamental mesmo é que, como 
"ciência do arquivo" de determinada época, esse arqueólogo específico tenta mostrar o "jogo de regras que determinam em uma cultura a aparição e o desaparecimento de enunciados, sua recomposição e seu apagar-se, sua existência paradoxal de acontecimentos e de coisas" (FOUCAULT, "Sur l'archéologie des sciences. Réponse au Cercle d'épistémologie", DE, I, 2001, p. 736). Dito desta maneira, na proposta arqueológica não se trata de fazer uma história da linguagem (FOUCAULT, "Préface", DE, I, 2001, p. 188), nem uma história da filosofia, mas uma "arqueologia do pensamento" (FOUCAULT, “Nietzsche, Freud, Marx", DE, I, 1994, p. 575).

\section{Do "filósofo" ao crítico "pluralista"}

Buscar-se-á mostrar melhor adiante com Kant, na direção das "ressonâncias" do pensamento deste em Michel Foucault, como o papel da Filosofia é inconteste: ela deve auxiliar o homem a perceber a importância de certa autonomia do pensar, e servir como "diagnóstico" do tempo presente. Uma filosofia que quer se recusar a ser apenas especulativa, como se vê em "Os intelectuais e o poder", quando Foucault e Deleuze sustentam a necessidade de fazer da teoria uma caixa de ferramentas: ela, teoria ou ideia, precisa servir para algo, para transformar o mundo ou então para transformar aquele que teoriza (FOUCAULT, 1979).

Sobra, porém, uma questão anterior ou primeira a ser respondida, e que Foucault não deixou de fazer, sendo isso necessário para a compreensão do papel crítico da sua Filosofia ou do seu empreendimento teórico. Pois, afinal, quanto à Filosofia - "isto" existe? Falando no recente século XX tal 
fora também uma questão heideggeriana, ao perguntar: "Que é isto - a Filosofia?" (HEIDEGGER, 1979). A resposta de Foucault não encontra aí um paralelo, na medida em que a sua posição envolve uma compreensão totalmente diferente com respeito à tradição filosófica, e na medida em que não está em jogo uma tentativa ontológica de conceituação, mas a observância do seu papel social e histórico. É certo que ainda é possível pensar nos filósofos, pessoas cujas atividades e discursos viriam com o tempo e distintos pelos caminhos que percorrem. Poder-se-ia mesmo pensar em uma tendência: por exemplo, na Alemanha, a preocupação com o Estado (vide Fichte, Hegel e Nietzsche); ou, na França, com a instituição pública, com a liberdade de pensamento e a liberdade individual. Mas se a filosofia mesma existe, disso "Eu não estou seguro", diz Foucault (FOUCAULT, "Le piège de Vincennes", DE, I, 2001, p. 938).

Na entrevista "Qu'est-ce qu'un philosophe" (DE, I, 1994, p. 553) Michel Foucault faz um ligeiro passeio por algumas figuras importantes da tradição filosófica, tentando responder à questão do papel do filósofo na sociedade, ou melhor, tentando justificar mesmo a ideia de que este nunca teve função específica. Sócrates, por exemplo, era um "subversivo", Descartes era professor de matemática e Kant professor de antropologia e geografia. Só com Hegel é que se forma efetivamente uma cadeira de filosofia, mas cujo papel não permanece aí inalterado, sobretudo na sua ambição de se constituir como sistema interpretativo do mundo.

Mas colocar as coisas dessa maneira era complicado, porque se acreditava que a filosofia tivera papel decisivo, como sustentaram significativamente vários pensadores. Não é 
preciso ir muito além de alguns autores importantes: a obra de Marx, por exemplo, esforçara-se para desmascarar as ilusões ou as falsas ideias dos discursos que, em função de uma lógica mancomunada com as classes burguesas escondiam na verdade injustiças e distorções sociais. De um ponto de vista geral os homens, diziam Marx e Engels logo no Prefácio de A Ideologia Alemã, "têm sempre criado representações falsas sobre si próprios, e daquilo que são ou devem ser" (1981, p. 17). Mais perto temporalmente, numa conferência que se tornara célebre, Edmund Husserl proferira em tom algo profético: "A filosofia deverá exercer, constantemente, no seio da comunidade européia, sua função diretriz [die archontische] sobre toda a humanidade" (HUSSERL, 2002, p. 82). Sartre (2002), apesar de ter identificado a sua própria filosofia como uma ideologia, reservou para aquela um papel imprescindível. Por fim, o próprio Deleuze, tão próximo de Foucault, chegou mesmo a rebater, inclusive pensando nos jovens, o malogro da filosofia. Nas suas palavras: "A resposta segundo a qual a grandeza da filosofia estaria justamente em não servir para nada é um coquetismo que não tem graça nem mesmo para os jovens" (DELEUZE, 1996, p. 14).

No parágrafo acima juntou-se, como no dito popular, "alhos com bugalhos". Cioso da sua tradição filosófica Michel Foucault vai fazer uma distinção entre uma linha racional dialética e uma analítica, e coloca a ideia segundo a qual nem toda a filosofia deveria ser enaltecida de igual modo. Assim, do primeiro bloco criticado por ele há pensamentos tornados possíveis a partir da colocação do homem como objeto de saber: nasceram daí filosofias da história, da reconciliação, da alienação, humanista em sua base, e, portanto, prometéica: cabe buscar no homem a sua autenticidade e verdade 
perdidas. Alguns dos seus representantes foram os marxistas "fracos" (mous), Saint-Exupéry, Camus e Teilhard de Chardin, "figuras pálidas da nossa cultura" (FOUCAULT, "Le homme est-il mort?", DE, I, 1994, p. 541), cuja fonte tomaram de empréstimo quinhões de Hegel e Marx em sua gênese.

E se Hegel é percebido como um filósofo cuja perspectiva se tornou obsoleta foi porque, com o surgimento das Ciências Humanas no século XIX, como um dos fatores principais, a filosofia perdera o seu status privilegiado "com respeito ao conhecimento em geral, e à ciência, em particular" (FOUCAULT, "La philosophie structuraliste permet le diagnostiquer ce qu'est 'aujourd'hui", DE, I 1994, p. 580.). Ela deixou de ser uma "especulação autônoma sobre o mundo" para se tornar uma espécie de atividade engajada em campos diversos.

Por fim, o próprio Sartre entra no rol dessa desvalorização: a sua Critica da razão dialética foi o "magnífico e patético esforço de um homem do século XIX para pensar o século XX" (FOUCAULT, “L'homme est-il mort?”, DE, I, 1994, p. 541). No outro lado, o da tradição não humanista (que sinaliza para a "filosofia de hoje"), encontra-se primeira e fundamentalmente Friedrich Nietzsche, cuja linhagem, mutatis mutandis, aportou na filosofia analítica de Russerll, em Wittgenstein, em linguísticas e sociólogos (Lévi-Strauss é citado na entrevista em causa) e em Heidegger.

De um modo que parece radical Foucault às vezes não economizava palavras fortes, chegando até a dizer que os filósofos não trabalhavam, que a filosofia "já está abolida", vaga disciplina universitária com a qual se fala acerca de questões longe do real: "a totalidade da entidade, da escritura, da 
'materialidade do significante', e de outras coisas parecidas" (FOUCAULT, “Le grand enfermement”, DE, I, 2001, p. 1173). Isso não significava, entretanto, que ele se precipitava para algum ceticismo ou niilismo. Em um outro momento, falando acerca da sociedade atual, na sua amplidão e complexidade, dá a ideia de que cabe ao intelectual (sentido mais abrangente do que filósofo) transformar o saber inconsciente contido no homem, além dos efeitos desse saber, em algo consciente (FOUCAULT, "Sexualité et pouvoir", DE, III, 1994, p. 595).

O problema não estava, portanto, em um descrédito mais ou menos declarado dado ao pensar, refletindo-se na desconfiança do trabalho intelectivo. A maneira de se entender esse novo "isto" em aberto - o intelectual - na relação teoria -prática, é que era a chave da questão. Novamente aqui cabe avaliar a tradição, recusando a ideia ainda presente do "intelectual universal" ou "intelectual profeta", como vai escrever algumas vezes (FOUCAULT, "Qu'appelle-t-on punir", DE, IV, 1994, p. 638). Esta figura fora derivada, tal como funcionou nos séculos XIX e XX, do homem da justiça, da lei, que contra o despotismo, o poder, a arrogância da riqueza, opôs a universalidade da justiça e a equidade da lei. Voltaire a encarna, sendo um intelectual não no sentido sociológico ou profissional, mas no sentido político, que faz uso do seu saber e competência. Sua expressão maior era o de ser o homem da escrita, distinto daqueles que detinham a competência ao nível do Estado ou do capital - os engenheiros, magistrados etc. (FOUCAULT, "La fonction politique de l'intellectuel", DE, III, 1994, p. 109-111).

Ao mesmo tempo "ser intelectual era um pouco a consciência de todos". Tal foi a ideia transportada ao marxismo, 
acha Foucault, ao colocar o proletariado como portador do universal; então, o intelectual, "por sua escolha moral, teórica e política", quer portar essa universalidade na forma de uma consciência clara e elaborada, enquanto o operário o faria de maneira imediata, irrefletida, "pouco consciente dele mesmo" (FOUCAULT, "La fonction politique de l'intellectuel, DE, III, 1994, p. 109). Mas então o pensar é privilégio de alguns? Acredita-se aqui que essa recusa foucaultiana está muito próxima de Kant.

Outra, porém, é a gênese do "intelectual específico". Para Foucault este derivara do sábio-expert, começando por Darwin e os evolucionistas, fazendo suas teorias resvalarem para os campos da sociologia, criminologia, psiquiatria etc. A Biologia, mais a Física, são as zonas privilegiadas para a formação desse novo intelectual, e é justamente aí que entra, a partir da Segunda Grande Guerra Mundial, Oppenheimer. Este cientista, ao unir ao mesmo tempo em sua figura o intelectual específico: era expert em energia nuclear - e o intelectual universal: seu saber concernia a toda a humanidade, através da ameaça atômica - demonstrou que sua função política vinha não do discurso que proferia, mas do saber que detinha e, com este, todo o perigo político em causa (FOUCAULT, “La fonction politique de l'intellectuel”, DE, III, 1994, p. 111). Nesse sentido, "Pode-se dizer que no século XX todo homem que descobre ou que inventa, todo homem que muda alguma coisa no mundo, o conhecimento ou a vida dos homens é, por uma parte, um filósofo" (FOUCAULT, "La philosophie structuraliste permet le diagnostiquer ce qu'est 'aujourd'hui'", DE, I, 1994, p. 580). 
Aliado a isso houve na verdade uma mutação das repartições do saber. Nos séculos XIV e XV ele era "o segredo"; sua autenticidade era garantida e protegida por um número restrito de indivíduos. Se se tornava público, deixava de ser verdadeiro, ao passo que hoje, como herdeiros de mudanças começadas nos séculos XVII e XVIII, o saber se tornara coisa pública. Todos o têm, embora não no mesmo campo, nem no mesmo grau de formação e precisão. Não há mais lados definidos: os conhecedores e os ignorantes, e nunca os campos de saber se comunicaram com tanta rapidez (FOUCAULT, “Foucault répond à Sartre”, DE, I, 1994, p. 668).

A questão foucaultiana, assim, não visa a abolir a filosofia e seu papel, ao conduzir para algo da ordem do ceticismo ou do niilismo. Trata-se de, em se partindo da figura mais ampla do intelectual, ${ }^{16}$ super-dimensionar o seu continente. Só é justo falar que a filosofia não existe mais ou desapareceu no sentido de que ela se dispersou ou "se disseminou em uma grande quantidade de atividades diversas" (FOUCAULT, "Sur les façons d'écrire l'histoire", DE, I, 1994, p. 597). Dessa forma, um matemático, um médico, um engenheiro podem ser filósofos e intelectuais. As suas especialidades interessam às massas sim, apesar de eles não trabalharem mais no universal, no exemplar, no "justo-e-verdadeiro-para-todos", mas em suas atividades precisas ligadas a certas condições de trabalho: o canteiro de obras, o asilo etc. (FOUCAULT, "Intervista a Michel Foucault" ('Entretien avec Michel Foucault'), DE, III, 1994, p. 154).

16 Quando Foucault quis conceder voz aos detentos, na sua pesquisa sobre o sistema prisional, a figura do intelectual foi novamente "diminuída", por assim dizer; mas o fundamental era dar direito de voz àqueles que vivem diretamente seus problemas. 
Pode-se objetar que os especialistas-intelectuais prestam serviço ao Estado e ao capital. Geralmente é verdade. Porém, Foucault entende isso como algo de positivo, pois mostra o lugar estratégico que eles ocupam. Afinal, a maior parte das funções do poder que encontra aqui ou ali resistência dos indivíduos não "se difundem pelas vias do saber" (FOUCAULT, "L'incorporation de l'hôpital dans la technologie moderne", DE, III, 1994, p. 530)? Quem se liga diretamente a essa rede, um médico, um advogado etc., em suas tarefas específicas, tem as informações necessárias do que, como área específica, é confidencial, restrito ou escondido. Por isso tem os meios para o exercício do contra-poder (FOUCAULT, “L'incorporation de l'hôpital dans la technologie moderne”, DE, III, 1994, p. 530).

Outra objeção é que eles seriam veículos de uma ideologia cientificista. Quanto a isso, nem sempre é o caso e, ademais, a questão não estava na relação ciência/ideologia, mas na relação verdade/poder. Foucault chegou a manifestar que os problemas abordados pelo velho intelectual universal, defensor do proletariado, e pela nova onda do intelectual específico terminavam sendo os mesmos (embora ambos não estivessem nas mesmas posições estratégicas): as multinacionais, o aparelho judiciário e policial, a especulação imobiliária (FOUCAULT, "Intervista a Michel Foucault" ('Entretien avec Michel Foucault'), DE, III, 1994, p. 154). Via-se, porém, que havia aí uma "consciência muito mais concreta e imediata das lutas": as lutas de conjuntura, as reivindicações setoriais eram lutas muito mais reais, quotidianas, materiais (FOUCAULT, "La fonction politique de l'intellectuel", DE, III, 1994, p. 109). Ora, justamente por conta disso é que cresciam, mas eram inevitáveis, inúmeros riscos e obstáculos: de se deixarem manipular por partidos políticos ou aparelhos sindicais; de ficarem 
impossibilitados de desenvolver as lutas por falta de estratégias globais e apoios exteriores.

Esse "pragmatismo" foucaultiano tenta responder, enfim, à pergunta capital feita no início do presente tópico: afinal, o que é a filosofia? Em "Folie, littérature, société" a resposta encontrada é que ela é "o lugar de uma escolha original, que se encontra na base de toda uma cultura", escolha como algo que "delimita todo um conjunto constituído pelo saber humano, as atividades humanas, a percepção e a sensibilidade". Entendendo que a filosofia hoje [1970] "provavelmente" já perdera o seu papel, função e autonomia, ${ }^{17}$ a direção defendida por Michel Foucault explica porque ele se interessou e se apoiou mais na literatura do que na filosofia: aquela é "o lugar onde nossa cultura operou escolhas originais" (FOUCAULT, “Folie, littérature, société", DE, I, 2001, p. 974).

Assim, por que a partir do século XVII o louco foi transformado em marginal, sendo submetido a todo um aparato de polícia, a um sistema prisional e a trabalhos forçados, além de formas ocidentais de disciplinas então criadas? E a nossa forma de lidar com o tema da sexualidade? Se Michel Foucault pode ser considerado um filósofo é antes por ter buscado compreender essas escolhas originais engendradas por nossa cultura, aquilo que ela rejeita ou exclui e aquilo que aceita ou tolera, ao invés de buscar algo como uma filosofia pura. Daí ele dizer que Freud, com sua investigação sobre a neurose e a loucura, fez uma escolha original "bem mais importante para nossa cultura do que as escolhas filosóficas de seus

17 Hegel teria sido o último filósofo a juntar escolha original e filosofia como atividade autônoma (FOUCAULT, "Folie, littérature, société", DE, I, 2001, p. 976). 
contemporâneos, como Bergson ou Husserl" (FOUCAULT, “Folie, littérature, société", DE, I, 2001, p. 974).

Se o filósofo profissional ou autônomo não encontra mais o seu lugar na ordem das coisas atuais, algo que se acrescenta ao que foi dito mais acima é a valorização foucaultiana de uma tendência vinda desde Nietzsche: a de distender o campo de investigação filosófica ou, como diz Foucault, de "multiplicar os gestos filosóficos" ("Michel Foucault et Gilles Deleuze veulent rendre à Nietzsche son vrai visage", DE, I, 1994). Com efeito, a partir de Nietzsche tais horizontes são ampliados, para além das disciplinas ou temas tradicionais recorrentes, a saber, não só uma gnosiologia ou uma ética (etc.), mas também uma literatura, história ou política vão exigir seu lugar no plano filosófico de reflexão. Modernamente a distensão desses novos caminhos, conforme comenta Michel Foucault em 1966, na entrevista com C. Jannoud (FOUCAULT, “Michel Foucault et Gilles Deleuze veulent rendre à Nietzsche son vrai visage", DE, I, 1994, p. 552), ${ }^{18}$ deu-se a partir de estudos etnológicos, lingüísticos, sociológicos e psicológicos ou, mais propriamente, da corrente estruturalista. Um personagem conceitual que ele vai assumir?

Numa entrevista publicada no Le Monde em 1961, "La folie n'existe que dans une société" (FOUCAULT, DE, I, 1994, p. 196), bem como na sua aula inaugural no Collège de France, nas suas partes finais, há relatos sobre as influências sofridas por Foucault para escrever Histoire de la folie. Nelas, ele rende homenagens a Maurice Blanchot e Raymond Roussel,

18 Foram Nietzsche, Freud e Marx que "fundaram de novo a possibilidade de uma hermenêutica", mais do que Descartes e Bacon e suas críticas à representação medieval (FOUCAULT, "Qu'est-ce qu'un philosophe", DE, I, 1994, p. 556). 
Dumézil, Canguilhem e Hyppolite (1996, p. 70-79). Mas Foucault vai apontar a importância, sobretudo, da obra de Dumézil. Acerca de tais influências foucaultianas o que interessa aqui é mencionar a idéia de "estrutura" neste último, endereçada aos mitos; pois com esta foi possível a Foucault fazer algo similar no tocante à loucura. Como apontou Didier Eribon, a diferença entre ambos é que Foucault não se preocupou em detectar "uma mesma estrutura através de suas múltiplas encarnações históricas e geográficas, mas de mostrar mudanças, rupturas que se instauram sob a superfície da história" (ERIBON, 1996, p. 91). ${ }^{19}$

Para Foucault o Estruturalismo foi um método que fundou certas ciências, como a lingüística; não obstante, pode-se dizer que ele também representou certa "atividade" filosófica, na medida em que pretendera, em diversos campos, "definir as relações atuais que podem existir entre tal e tal elemento de nossa cultura" (FOUCAULT, "La philosophie structuraliste permet le diagnostiquer ce qu'est 'aujourd'hui", DE, I, 1994, p. 581). E este é um dos aspectos fundamentais pelo qual é possível conceber o filósofo: aquele que, hodiernamente [1967], tornou-se "uma espécie de analista da conjuntura cultural", como já foi citado tópicos atrás, cultura aqui entendida em sentido largo, para além de se referir apenas à

19 A estrutura da qual ele se refere terá a ver com aquela relativa à "segregação social", à "exclusão" (FOUCAULT, "La folie n'existe que dans une société", DE, I, 2001, p. 196), tendo em vista que não se está diante de um fenômeno puro a ser desnudado. Falando de loucos e sãos é sempre na perspectiva de que há um contexto social por detrás, uma "sensibilidade" que apreende a loucura (FOUCAULT, "La folie n'existe que dans une société", DE, I, 2001, p. 197), impossível se estivesse fora dos muros da sociedade. 
produção de obras de arte, mas também às "instituições políticas, formas de vida social, interditos e imposições diversas" (FOUCAULT, "La philosophie structuraliste permet le diagnostiquer ce qu'est 'aujourd'hui', DE, I, 1994, p. 582).

Romando a noção foucaultiana de evidência, por exemplo, se os discursos nascem da contingência histórica de condições e regras específicas, há de se pontuar que esses determinantes, para Foucault, são inconscientes: "existe um inconsciente do saber que tem suas formas e suas regras específicas" (FOUCAULT, "Réponse à Derrida", DE, I, 2001, p. 1152). Viu-se que, na análise arqueológica, há de se tentar perceber não os discursos na sua relação direta entre significante e significado, mas as regras que tornam possíveis, como tais, a produção desses discursos. Regras manifestas, mas que não são vistas tão diretamente (inconsciente do saber), o estruturalista trabalhará com algo semelhante, um lado inconsciente presente nas mais diversas estruturas..$^{20}$

20 O trabalho de Lévi-Strauss, Antropologia estrutural, 1989, especialmente o capítulo II, "A análise estrutural em lingüística e em antropologia", traz um bom entendimento acerca das noções fundamentais do estruturalismo, abordando questões como a passagem dos fenômenos lingüísticos conscientes para a sua infra-estrutura inconsciente (e se são inconscientes, não são vivenciadas, só experimentadas), o fato de que os termos não são tomados isoladamente, mas nas suas relações entre si, oposições e diferenças (sentido imanente x sentido de posição), aborda a noção de sistema (modificando-se um dos elementos, todos os outros serão modificados), a procura de leis gerais e universais, seu caráter arbitrário, a diferença entre sincronia x diacronia, e a presença de regras, elementos e analogia com o jogo. Deleuze, em "Como se pode reconhecer o estruturalismo" (1982), faz ainda observar a existência da tríade real/simbólico/imaginário (por exemplo, o complexo de Édipo de Freud seria um caso particular da versão estruturalista). 
Outra posição foucaultiana favorável ao estruturalismo tinha a ver com a solução dada para a quase necessidade de defender, no trabalho teórico, alguma espécie de engajamento político e preocupação com mudanças sociais. Os anos 50 do século XX tinham feito emergir um Existencialismo preocupado com o homem e seus horrores, por assim dizer, como os oriundos da Segunda Grande Guerra mundial e, consequentemente, com o sentido a se conferir à própria vida humana. Uma teoria deveria seguir, pois, antes de tudo, essa linha. Mas como pensar no conceito de engajamento?

Para Michel Foucault uma teoria "engajada" não precisaria se aliar aos "velhos valores liberais e humanistas" (FOUCAULT, "Interview avec Michel Foucault", DE, I, 1994, p. 655). Histoire de la Folie não mostrou o engodo existente entre a relação filantropia/barbárie, onde as mudanças ocorrem mais por uma necessidade estratégica de perpetuar as formas de dominação? (FOUCAULT, 2003a, p. 534.). Não mostrou que existe, na verdade, uma tendência de "medicalização geral da existência", que não se restringiu à idade clássica, e que não se alinha com uma visão equivocada de um humanismo despretensioso e ingênuo? ("Le pouvoir, une bête magnifique". DE, III, 1994, p. 373). Afinal, esse mesmo humanismo não "serviu para justificar, em 1948, o stalinismo e a hegemonia da democracia cristã"? Será mesmo que tem fundamento a ideia em crisálida no Humanismo segundo a qual "o fim da política é a felicidade" (FOUCAULT, "Qui êtes-vous, professeur Foucault?", DE, I, 1994, p. 616), com sua ligação, desde o século XIX, ao "sonho do homem feliz"? (FOUCAULT, "Interview avec Michel Foucault", DE, I, 1994, p. 651)? 
Ora, um recorte teórico não humanista deveria fornecer as melhores armas possíveis para operar na sociedade as mudanças requeridas, caso os meios mais sutis não atendessem às expectativas, e o Estruturalismo foi nessa direção, preferindo desenvolver-se como atividade teórica e científica, ainda que entendida por alguns como um trabalho apurado, mas marginal, contenda que fez Michel Foucault ponderar o projeto sartreano. Ou seja, nas idas e vindas de Foucault a Sartre, aquele lembra "sem ironia" do empenho deste em criticar os governos burgueses reacionários, como o stalinismo, análises condizentes com aquele período histórico, "muito belas e muito conseqüentes"; e não obstante é taxativo ao dizer que as coisas mudam em todos os domínios.

Nesse ano de 1968 Foucault exaltava a tranqüilidade da vida burguesa, com a qual permitia levar avante os referidos estudos marginais: por exemplo, a sexualidade em tribos primitivas ou o estudo de um romance do século XIX na sua estrutura - e assim mesmo reafirmava certo liame entre eles e algum engajamento político. Mais propriamente, o Estruturalismo deveria servir como instrumento de análise para a ação política, já que "A política não está necessariamente entregue à ignorância" (FOUCAULT, "Interview avec Michel Foucault", DE, I, 1994, p. 686).

Ilustra-se isso com a distinção filosófica foucaultiana entre saber objetivo e saber totalizante. Quando Sausseare marcou no seu trabalho uma diferença entre a fala e a língua, privilegiando esta, ele (como outros tantos estruturalistas ao seu modo) tomou partido por uma "operação de tipo filosófico" bastante peculiar; a saber, visou a um "domínio objetivo", ao invés de buscar fazer uma "atividade totalizante", como em 
Husserl, que pretendera investigar "o conjunto de nosso universo de conhecimentos" (FOUCAULT, "Qui êtes-vous, professeur Foucault?", DE, I, 1994, p. 612).

Em outra entrevista, "Le grand enfermement", ao perguntarem a Foucault se havia filósofos sérios que totalizam, como Sartre, sua resposta foi afirmativa, seguida de um "longo silêncio". Sim, ele é sério, mas "em toda parte onde Sartre totaliza, ele se afasta da realidade. E cada vez que ele se apodera de um problema determinado, que ele tem uma estratégia determinada, que ele luta, aproxima-se da realidade" (FOUCAULT, "Le grand enfermement", DE, I, 2001, p. 1173). Totalizar é também "querer fazer da análise histórica o discurso do contínuo", da consciência humana o sujeito originário de todo saber e prática (FOUCAULT, "Sur l'archéologie des sciences. Réponse au cercle d'épistémologie", DE, I, 2001, p. 727). Quando a psicanálise despossuiu o sujeito das leis de seu desejo, os lingüistas das formas de sua palavra, os etnólogos das regras de sua ação, tudo ruiu, quer dizer, as totalizações se tornaram obsoletas, e as "grandes sínteses" igualmente deveriam cair por terra: a noção de tradição, com suas "coordenadas permanentes"; a linha de um desenvolvimento por detrás dos acontecimentos; a teleologia ou evolução; a mentalidade ou o "espírito de uma época" (FOUCAULT, "Sur l'archéologie des sciences. Réponse au cercle d'épistémologie", DE, I, 2001, p. 729). Enfim, pesquisas regionais, ao invés de pesquisas totalizantes: sinais dos novos tempos...

Chegando nesse ponto, duas conseqüências a tirar: primeiro, o Estruturalismo não seria um trabalho apenas diletante. Foucault o vê não só como atividade teórica, mas também podendo se articular em algo como uma prática; segundo, 
haveria no Estruturalismo implicações morais e políticas, pois sendo uma análise teórica exata de como funcionam as estruturas econômicas, políticas e ideológicas, isso seria condição necessária para a ação política, esta podendo, estão, manipular e quiçá transformar tais estruturas (FOUCAULT, "Réponse à une question", DE, I, 1994, p. 683). Afinal, a renovada concepção de "engajamento" não poderia se filiar a alguma espécie de "douta ignorância".

Assim, não foi à toa que a imagem de um Foucault estruturalista percorreu tantos lugares. Do ponto de vista teórico muitas aproximações saltavam à vista. Não obstante Michel Foucault ter recusado de ser chamado como um membro desta corrente, de portar tal imagem (como o foram LéviStrauss, Lacan, Piaget, Jakobson, Dumézil etc.), apesar de tantas simpatias. Ou seja, sem se identificar do "interior" com o Estruturalismo, à altura desses representantes acima, sem querer inclusive conceituá-lo, já que isso caberia aos seus opositores, dizia-se assemelhar-se a eles do "exterior": todos excluíam o sujeito humano, a consciência e a existência em sua centralidade e pertinência teórica (FOUCAULT, "Réponse à une question", DE, I, 1994, p. 681). E foi baseado em direcionamentos teóricos como esses que Foucault se julgou aproximar-se desta corrente, a exemplo da entrevista "Qui êtes-vous, professeur Foucault?", quando diz ter sido o problema da relação sincronia-diacronia algo menor, se comparado à recusa da soberania do sujeito ou consciência (FOUCAULT, "Qui êtes-vous, professeur Foucault?", DE, I, 1994, p. 611). Ou seja, que o sujeito não domina a sua consciência, a sua linguagem ou mesmo o seu saber (FOUCAULT, "Interview avec Michel Foucault", DE, I, 1994, p. 659). 
Em "Michel Foucault explique son dernier livre" diz estar, quanto ao Estruturalismo, "ao lado dele, não nele" [à côté de lui, pas en lui] (FOUCAULT, "Michel Foucault explique son dernier livre", DE, I, 1994, p. 779), embora, de 1969, onde se retira tal expressão, até o ano de 1976 (FOUCAULT, "Hanzai tosite no chishiki” ('Le savoir comme crime'), DE, III, 1994, p. 80), ele chegasse mesmo dizer que "ignorava" o Estruturalismo e que este "não o interessava". Frase excessiva e até incompreensível, em se partindo de tudo aquilo que Foucault chegou a dizer? Sim, a menos que se compreenda que ele estava muito mais interessado, como disse em L'archéologie du savoir (FOUCAULT, 2003b, p. 12-15), em realçar as novas tendências da abordagem histórica (história serial, tendo o Estruturalismo "reativado" a crítica a uma história contínua e linear), crítica que já estava presente no tratamento dado pela história econômica.

Outra coisa é que, neste mesmo ano de 1967, Michel Foucault chega a dizer que "O sistema é nossa forma maior de honestidade" (FOUCAULT, "La philosophie structuraliste permet le diagnostiquer ce qu'est 'aujourd'hui", DE, I 1994, p. 582), clara alusão a um projeto teórico ou mesmo a uma compreensão teórica da sua época ainda em se fazendo. Ao mesmo tempo, marcando uma posição bastante particular do seu empreendimento, diz ter tentado "introduzir análises de estilo estruturalista em domínios onde eles não tinham penetrado até o presente" (FOUCAULT, "La philosophie structuraliste permet le diagnostiquer ce qu'est 'aujourd'hui", DE, I, 1994, p. 583), isto é, história das ideias, dos conhecimentos e da teoria. 
A questão era, apesar de tantas valorizações, demarcar devidamente as suas diferenças. Algo que aparece com clareza no artigo "Réponse à une question", um ano depois (1968), onde Foucault diz não se interessar pelo "sistema de sua língua", uma vez que o foco de interesse não são os códigos, mas os acontecimentos e, dentro deste, tentar perceber "a lei de existência dos enunciados, o que os tornam possíveis", trabalho arqueológico de descrição do arquivo (FOUCAULT, “Réponse à une question", DE, I, 1994, p. 681). Ou seja, a partir de uma análise da linguagem, como chegar à estrutura e perceber o sentido no qual este permanece condicionado àquela? O mote foucaultiano não vai por aí, uma vez que o seu interesse esteve voltado para a noção de função: algo, por exemplo, foi dito em algum momento, provocando certos efeitos. Volta-se à ideia de acontecimento (FOUCAULT, “Dialogue sur le pouvoir", DE, III, 1994, p. 467). ${ }^{21}$

Em "La folie et la société" (FOUCAULT, DE, III, 1994) Foucault sente a necessidade de se inserir no embate existente entre o método de análise fenomenológico e o estrutural. No argumento da primeira corrente, a análise estrutural não poderia ser histórica, pois tanto privilegia o simultâneo sobre o sucessivo, quanto à lógica do sistema frente a causalidades, de nada valendo no sentido de uma análise das mudanças e transformações (FOUCAULT, "La folie et la société", DE, III, 1994, p. 493). O Estruturalismo, do qual Foucault defende, ao lado de historiadores mais modernos, como Veyne, pensa em

21 Em microfísica do poder, precisamente em "verdade e poder" (1992), Foucault tenta salvar a ideia de acontecimento, para além do viés interpretativo dos estruturalistas. Em "Sur les façons d'écrire l'histoire" (FOUCAULT, DE, I, 1994, p. 599) diz que sua arqueologia deveu-se mais a genealogia nietzscheana do que ao Estruturalismo. 
ver justamente o contrário. É preciso na verdade abandonar "a grande e velha metáfora biológica da vida e da evolução" que, em sua forma ideológica, dizia ser a história algo que durava em analogia com o ser vivo (FOUCAULT, "Revenir à l'histoire", DE, I, 2001, p. 1149). Pensando assim, se na vida não há revolução violenta, se só há lenta acumulação de pequenas mudanças, igualmente a história não poderia ser o palco de violentas revoluções.

Em vários momentos e obras Veyne aparece na defesa de Michel Foucault. Em Foucault: sa pensée, sa personne escreve um pouco sobre o despreparo de muitos historiadores:

Assim, Foucault esperava ver a escola histórica francesa abrir-se às suas ideias; depositava todas as esperanças nela; não era uma elite de espírito aberto cuja reputação era internacional? Não estavam preparados para admitir que tudo era histórico, até mesmo a verdade? Que não existia invariantes transhistóricas? Inflizmente, para ele, esses historiadores estavam então ocupados com seu próprio projeto, o de explicar a história relacionando-a com a sociedade; nos livros de Foucault eles não encontravam realidades que eles tinham por regra buscar numa sociedade, encontravam problemas que não eram os deles, o do discurso, o de uma história da verdade (VEYNE, 2010, p. 43)

Ora, não se pode apreender a história sob uma lente positivista, tentando discernir, a partir das suas ocorrências, situações, acontecimentos a razão de ser definitiva de tudo 
isso. Para Veyne, a história é uma "ideia-limite"; ou antes, "A ideia de história é um limite inacessível", quer dizer, "uma ideia transcendental", na medida em que não existe uma história total (VEYNE, 1978, p. 41). Para Veyne, Foucault mostra a expessura não dos aconteciemtos históricos como tais, mas, diante das ocorrências nascidas no tecido da história, a emergência dos discursos, jamais apreendidos como espelhos de algum tipo de realidade: "Foucault não acredita nesse espelho, nessa concepção 'especular' do saber: segundo ele, o objeto, em sua materialidade não pode ser separado dos quadros formais através dos quais nós o conhecemos e que Foucault, com uma palavra mal escolhida, chama 'discurso'" (VEYNE, 2010, p. 14)

Os fenomenólogos e outros críticos não perceberam a mudança da nova abordagem histórica que batia à porta e sua inclinação a favor das transformações da sociedade. Enfim, os novos historiadores, como os estruturalistas, vão buscar interpretar não o material em evidência, mas fazer aparecer relações e sistemas de relações (FOUCAULT, "Revenir à la histoire", DE, I, 2001, p. 1144-1148), e esse trabalho tão apurado só poderia ser positivo: "o Estruturalismo e a história contemporânea são instrumentos teóricos graças aos quais pode-se, contra a velha ideia da continuidade, pensar realmente a descontinuidade dos acontecimentos e a transformação das sociedades". Ou ainda, em "La folie et la société": "não há Estruturalismo que não seja, de uma certa maneira, a análise das condições necessárias e suficientes para uma transformação possível" (FOUCAULT, DE, III, 1994, p. 493).

Parece ser plausível dizer que, nessa operação foucaultiana de repartir correntes e ideias, uma imagem geral de autor 
crítico começa a esboçar-se. Mas tal imagem, tornando-a como um conceito delimitado e operador, nem sempre caberá destaque, senão no artigo "Réponse à une question" (DE, I, 1994), onde buscará para si assumir a imagem de um autor "pluralista", seguindo-se a outros momentos mais importantes, objeto nesta tese do segundo e terceiro capítulos. Buscar-se-á agora entender preliminarmente o alcance daquela primeira referência mais detida na imagem de crítico, concluindo o então Capítulo I com os traços personalísticos mais recorrente em Michel Foucault.

A preocupação foucaultiana, em meio aos anos 60 , é contornar ou estabelecer um perímetro relativamente ao problema da linguagem ou do discurso e ele tenta fazê-lo a partir da necessidade de se pensar em como "individualizar" os discursos, em como estabelecer as "unidades discursivas". Esses critérios permanecerão posteriormente, na medida em que será negada a unidade discursiva "ciência" como objeto próprio de investigação.

Veja-se, por exemplo, dentro dos critérios de individuação apontados por Michel Foucault, o primeiro deles, os "critérios de formação". Para ele, o que vai individualizar um discurso não é a unidade de um objeto, uma estrutura formal, nem uma "arquitetura conceitual coerente", bem como uma "escolha filosófica fundamental". Se se fica aí o problema da verdade não é contornado, ou então da fundamentação lógica de um aparato discursivo e, obviamente, ficar-se-ia imerso em todos os (pseudo-) problemas que aparecem no seu desdobramento, sobretudo a demarcação e legitimidade dos diversos ramos do saber, sendo recorrente a velha indagação: como estabelecer critérios seguros de cientificidade? Melhor do 
que isso, porém, é compreender que pensar nos critérios de formação discursiva significa pensar antes na "existência de regras de formação" dos seus objetos, operações, conceitos e opções teóricas (FOUCAULT, "Réponse à une question", DE, I, 1994, p. 675).

O terceiro dos critérios, os de correlação, também é interessante aqui. ${ }^{22}$ Como um discurso se correlaciona com outros? Trata-se, fundamentalmente, de descrever as épistémes que aparecem ao olhar atento do arqueólogo, entendidas não como a soma de conhecimentos ou o "estilo geral de suas pesquisas", mas como as "distâncias, oposições, diferenças, relações de seus múltiplos discursos científicos" (FOUCAULT, “Réponse à une question", DE, I, 1994, p. 676).

Ao utilizar todos esses critérios Michel Foucault quer se opor a temas como história totalizante (progresso da razão ou "espírito de um século"), ou a noções como as de Weltansshaung (visão de mundo). O conhecimento não é a emergência do poder humano de, pari passu, dar conta de uma realidade que, disposta quase como em camadas de determinações escondidas, são-lhes retirados os véus, à medida da capacidade humana de avançar no desconhecido. O conhecimento desnuda ou coage? Desde os estudos foucaultianos sobre a história da loucura, passando pelos anos de 1970, onde a questão do poder vai ser privilegiada, até os seus últimos estudos acerca da história da sexualidade aparece cada vez mais a imagem de um conhecimento cheio de ardis e de propósitos escusos.

22 O segundo dos critérios é o de transformação, onde Foucault buscou estudar as formas pelas quais um discurso se modifica, seja nos seus objetos, operações, conceitos e opões teóricas. 
No artigo "Réponse à une question" outros temas de importância capital vão aparecer, cabendo destaque o problema da descontinuidade, a ser falado oportunamente. O que interessa agora é que Michel Foucault tentou caracterizar algo que chamou de operação crítica no seu trabalho, baseada em quatro princípios, ratificando um pouco aquilo que desde cedo fora direção dos seus estudos. Assim, em primeiro lugar deve-se estabelecer limites na história do pensamento, e em três frentes: de um lado há fronteiras assinaláveis nos discursos (suas regras de formação e condições de existência); de outro, pôr em questão o sujeito soberano; por fim, entender que na história não se deve buscar algo como uma origem perdida, ao invés de tentar assinalar as suas "condições de nascimento e de dispersão". Em resumo, questionar os temas origem, sujeito e significação implícita (FOUCAULT, “Réponse à une question”, DE, I, 1994, p. 684).

A segunda característica da operação crítica vai consistir em apagar ou se afastar [effacer] das "operações pouco refletidas", entendidas isso como entraves à pesquisa. Concretamente falando, abandonar uma gama enorme de oposições que se verificam em todos os lados, como: vivacidade das inovações versus o peso da tradição; inércia dos conhecimentos versus as velhas práticas do pensamento; as formas médias do saber ("mediocridade cotidiana") versus suas formas desviantes; períodos de estabilidade versus os de ebulição (as crises) (FOUCAULT, “Réponse à une question”, DE, I, 1994, p. 684).

A história, ao contrário, é o palco da "perpétua diferença", compreendida tanto pelas suas diferenças simultâneas ("que definem em uma época dada a dispersão possível do saber"), quanto pelas diferenças sucessivas ("que definem o conjunto 
das transformações, sua hierarquia, sua dependência, seu nível"). Em outras palavras, para ser fiel ao conceito foucaultiano, uma diferença perpétua consiste na narração da "história das ideias como conjunto das formas especificadas e descritivas da não identidade", o que, filosoficamente, significa recusar as linhas de interpretação históricas ligadas ao evolucionismo, ao biológico, na sua separação entre o inerte e o vivo, e ao dinâmico, na oposição entre movente e imóvel (FOUCAULT, “Réponse à une question", DE, I, 1994, p. 684-685).

A terceira tarefa crítica é "Levantar a denegação que teve por objeto o discurso em sua existência própria", ${ }^{23}$ constituindo para Michel Foucault "a mais importante das operações", a qual se divide em alguns aspectos assim resumidos: 1) "somente tratar o discurso como elemento indiferente, e sem consistência nem lei autóctone". Ou seja, não pensar que as coisas estão aí, dispostas de forma "muda" para o trabalho de "tradução" ou ainda de "expressão" para os pensamentos, imaginações, conhecimentos ou temas inconscientes; 2) "só reconhecer no discurso os recortes de um modelo psicológico e individualizante" (a obra de um autor de juventude ou de maturidade), "lingüístico ou retórico" (gênero ou estilo) e "semântico" (ideia ou tema); por fim, 3) "admitir que todas as operações são feitas antes do discurso e fora dele", quase que tornando o trabalho do dizer o que as coisas são um "excedente", na medida em que elas já o mostravam vivamente (FOUCAULT, “Réponse à une question”, DE, I, 1994, p. 685).

23 Segue-se aqui a tradução dos Ditos e escritos na sua edição brasileira (FOUCAULT, 2010, p. 13). 
A crítica empreendida nesses moldes, ou então a análise histórica feita a partir de tal princípio, não buscará, pois, o que se quis dizer ou o que ficou mudo, mas que deixou "marcas". O discurso proferido apenas perfaz o campo de suas possibilidades, e é a "diferença" entre esse possível e aquilo que foi efetivamente proferido o que importa observar. Em uma palavra perceber as "regras" alocadas internamente em cada aparato discursivo, regras moventes e não baseadas em um princípio de necessidade, não havendo sentido fazer um resgate das oposições pensamento-linguagem, história-verdade, fala-escrita e palavras-coisas. Daí a ironia do seu livro de 1966, Les mots et les choses.

A quarta tarefa crítica, uma espécie de resumo ou retomada de todas as outras três, consiste em liberar de seu status incerto esse conjunto de disciplinas chamadas de história das ideias, das ciências, do pensamento, dos conhecimentos, dos conceitos ou da consciência (FOUCAULT, "Réponse à une question", DE, I, 1994, p. 686). Esse status incerto referido por Michel Foucault aí traz a viva compreensão de que não é tão simples assim isolar os supra conjuntos, pois, afinal (e ele indica três caminhos problemáticos), 1) como delimitar os seus domínios ("onde termina a história das ciências, onde começa aquela das opiniões e das crenças?)? Como se dividem a história dos conceitos e a história das noções ou dos temas? Por onde passa o limite entre a história do conhecimento e aquela da imaginação?"? 2) como definir a natureza do objeto ("fazemos a história das formas mentais, ou a história de sua interferência? [Dos] traços característicos que pertencem em comum aos homens de uma época ou de uma cultura? Descrevemos um espírito coletivo? Analisamos a história (teleológica ou genética) da razão?" (FOUCAULT, "Réponse 
à une question", DE, I, 1994, p. 686). Por fim, 3) entre os fatos de pensamento ou conhecimento e outros domínios de análise histórica, como designar uma relação entre eles, a saber, "é preciso tratá-los como signos de outra coisa (de uma relação social, de uma situação política, de uma determinação econômica)? Ou como seu resultado? Ou como sua refração através de uma consciência? Ou como a expressão simbólica de sua forma de conjunto?" (FOUCAULT, "Réponse à une question", DE, I, 1994, p. 686)?

A tarefa crítica assim disposta no texto "Réponse à une question" aporta para uma saída diante de tantas "incertezas". Mas Foucault tenta fazê-lo não como uma fuga diante de alguma questão espinhosa, senão vendo a necessidade de se traçar outro caminho de análise. Ao invés de tratar dos discursos eles mesmos (consistência lógica, verdade etc.), pensa ser melhor tentar investigar as "suas condições de formação, na série de suas modificações e no jogo de suas dependências e de suas correlações", fazendo deste caminho uma análise "descritiva” (FOUCAULT, “Réponse à une question”, DE, I, 1994, p.686).

Mas o que tal análise reclamaria diferença em relação às obordagens tradicionais? É preciso lidar com "práticas discursivas nas relações específicas que as articulam com outras práticas" (FOUCAULT, “Réponse à une question”, DE, I, 1994, p.686), na direção menos de uma "história global" do que "geral" (FOUCAULT, "Réponse à une question", DE, I, 1994, p.686), e responder devidamente à ideia de uma "política progressista". Ou seja, falando em significação, origem e sujeito constituinte e soberano que, no seu conjunto, remetem a uma histórica teleológica como "presença inesgotável do Logos" 
está-se indo na contracorrente daquela postura. Não que a prática política tenha em Foucault algum sentido específico essencial ou fundamental, pois essa perspectiva essencialista nunca foi a sua proposta. De maneira mais modesta; talvez, melhor, com um senso muito claro de aspectos "precisos" a serem destacados, importa apenas dizer que algo no seu trabalho não deve ser "sem importância" para uma prática política, a saber, a compreensão do "estatuto, das condições de exercício, do funcionamento, da institucionalização dos discursos científicos" (FOUCAULT, "Réponse à une question", DE, I, 1994, p.688).

Foucault faz observar, na visada não das ciências dotadas de uma "estrutura epistemológica mais forte", como a matemática e a física, mas daquelas com um campo de positividade mais "denso" e "complexo", como medicina, economia e ciências humanas, que algumas "hipóteses" aceitas geralmente não são pacíficas: a de que a consciência e percepção dos homens se modificam em função das mudanças econômicas, sociais e políticas (como no caso da relação da medicina e das doenças); e, como segunda hipótese importante, que "as noções fundamentais da medicina clínica derivariam, por transposição, de uma prática política ou, ao menos, das formas teóricas nas quais ela se reflete" (FOUCAULT, "Réponse à une question", DE, I, 1994, p.689).

Para Foucault, contudo, não é bem assim a relação entre discurso científico e prática política. Esta última não transforma nem o sentido e nem a forma daquele, mas as suas "condições de emergência, de inserção e de funcionamento"; em uma palavra, o seu "modo de existência". Caso contrário poder-se-ia dizer que os conceitos criados por uma ciência (a 
médica, por exemplo) seriam traduções ou expressões daquelas condições. A prática política, ao invés, transformando o "sistema de sua formação", repercute nos diversos registros administrativos (como o das doenças, falecimentos, entradas e saídas hospitalares, relação médico-paciente), bem como em algumas outras dinâmicas sutis, como ele explica em uma passagem entre parêntesis:

(a substituição do conceito de 'tecido' pelo de 'sólido' não é, evidentemente, o resultado de uma mudança política; mas o que a prática política modificou é o sistema de formação dos conceitos: a notação intermitente dos efeitos da doença e à designação hipotética de uma causa funcional, ela permitiu a substituição de um quadriculado anatômico rigoroso, quase contínuo, escorado em profundidade, e a indicação local das anomalias, de seu campo de dispersão e de suas vias eventuais de difusão) (FOUCAULT, "Réponse à une question", DE, I, 1994, p.690).

Michel Foucault indica, pois, uma série de problemas ora abertos. Pode-se tentar descrever a relação direta e indireta entre discurso científico e prática política, sabendo-se que, respectivamente, são relações que não transcorrem na "consciência dos sujeitos falantes" ou eficácia do pensamento de alguém, e cujos comprometimentos não se dão como "expressão imediata de uma relação social ou de uma situação econômica"); pode-se dizer também que a prática política não faz nascer uma ciência, tornando-se assim o critério de sua cientificidade, já que apenas influi no seu modo de existência 
e funcionamento; que as articulações entre ambos repercutem em outras disciplinas (interdiscursividade); finalmente, que certos conceitos só ganham relevo de época para época, como no discurso médico, "em razão do estatuto dado (...) pela prática política" (FOUCAULT, "Réponse à une question”, DE, I, 1994, p. 691-692). A análise foucaultiana reclama a necessidade dessas investidas na "positividade" do saber. ${ }^{24}$

Eis, em resumo, as direções foucaultianas para uma política progressista: diminuir o papel das iniciativas individuais, de necessidades ideais ou "determinações unívocas", em prol do reconhecimento das condições históricas e de "regras específicas de uma prática"; perceber que as mudanças não acontecem a partir de um entendimento abstrato que se tem dela, ou da força "taumatúrgica do gênio"; que a noção de sujeito, homem ou consciência sinaliza mais para alguém que ocupa uma função em certo plano do que para um agente operador da história (FOUCAULT, "Réponse à une question", DE, I, 1994, p. 693). Mal-estar, descontentamento, situação insuportável essa de saber que o papel de agente ou de ator foi suplantado? O murmúrio de um discurso sem autor "não seria o lugar das imortalidades sem substância? Seria preciso admitir que o tempo do discurso não é o tempo da consciência levado às dimensões da história, ou o tempo da história

24 Se em Histoire de la folie a ideia de "formação discursiva" se refere às regras de formação de objetos, tipos sintáticos, elementos semânticos e operadores (FOUCAULT, "Sur l'archéologie des sciences. Réponse au cercle d'épistémologie", DE, I, 1994, p. 747) -, a "positividade" é o "sistema" desses "quatro níveis". (FOUCAULT, "Sur l'archéologie des sciences. Réponse au cercle d'épistémologie", DE, I, 1994, p. 736). Quer dizer, cada formação discursiva está ligada a certas condições e regras e suscetíveis a mudanças (FOUCAULT, "Réponse à une question", DE, I, 1994, p. 693). 
presente na forma da consciência?" O fato é que, nos inúmeros recuos históricos feitos por Michel Foucault, sua tentativa foi buscar compreender o homem de hoje, embora a pesquisa realizada não precisasse tê-lo elevado à figura soberana de consciência e ação (FOUCAULT, "Réponse à une question", DE, I, 1994, p. 694).

Por fim, Michel Foucault não vai esquecer de mencionar o papel da prática política relativamente ao discurso científico (acrescentando também a literatura, os enunciados religiosos e os discursos políticos). Para ele, todas essas formas de saber não são "o resultado de processos mudos ou a expressão de uma consciência silenciosa", sempre naquela perspectiva de um mundo a ser desvelado, mas práticas que se relacionam com outras práticas. Assim, a prática política deve menos se voltar para uma posição de "'demanda perpétua ou de 'crítica soberana'" com relação à ciência, do que buscar entender como se dá a sua positividade e como são feitas as suas articulações (FOUCAULT, “Réponse à une question”, DE, I, 1994, p. 693).

A relação ciência-prática política não deverá se esquecer das demandas da cultura:

Cada cultura define de uma maneira que lhe é particular o domínio dos sofrimentos, das anomalias, dos desvios, das perturbações funcionais, dos distúrbios de conduta referidos à medicina, que suscitam sua intervenção convocando de sua parte uma prática específica (FOUCAULT, “Médicins, juges et souciers au XVII siècle", DE, I, 1994, p. 753). 
Com o que está sendo dito Foucault sugere que a substituição de uma análise da ciência como tal pela análise do "saber", em sua apreensão arqueológica e em sua positividade, afasta-se de uma pesquisa voltada para uma ciência captada através da "memória dos seus erros passados ou de suas meia-verdades". ${ }^{25} \mathrm{Ou}$ seja, afasta-se mesmo de um trabalho epistemológico, epistemologia conceituada por ele como "análise interna da estrutura de uma ciência" (FOUCAULT, "Michel Foucault explique son dernier livre", DE, I, 1994, p. 754).

Ter sido um "jornalista" do acontecimento, repensado o trabalho do filósofo e do intelectual, pontuado as diferenças entre o historiador e o arqueólogo, ter valorizado não propriamente o método estruturalista, mas as direções teórico-filosóficas tomadas por tal corrente e, por fim, ser um crítico pluralista: acredita-se que essas imagens foram fundamentais em Michel Foucault, embora houvesse outras tantas a ele imputadas. E que fizeram parte da construção da ideia de autor crítico. Esta imagem, como se disse antes, vai crescer em importância e um momento fundamental será quando Foucault tentará refazer as pegadas de Kant e, depois, de Nietzsche. Perceber como esta crítica vai ser configurada é o passo a ser dado a seguir.

25 Como na perspectiva de Thomas Kuhn, por exemplo (KUHN, 1991). 